\title{
LOS DERECHOS DE LOS EXTRANJEROS EN LA CONSTITUCIÓN ESPAÑOLA Y EN LA JURISPRUDENCIA DEL TRIBUNAL EUROPEO DE DERECHOS HUMANOS
}

\author{
TERESA FREIXES \\ Catedrática de Derecho Constitucional \\ JOSÉ CARLOS REMOTTI CARBONELL \\ Profesor de Derecho Constitucional
}


SUMARIO 


\title{
LOS DERECHOS DE LOS EXTRANJEROS EN LA CONSTITUCIÓN ESPAÑOLA Y EN LA JURISPRUDENCIA DEL TRIBUNAL EUROPEO DE DERECHOS HUMANOS
}

\author{
TERESA FREIXES \\ Catedrática de Derecho Constitucional \\ JOSÉ CARLOS REMOTTI CARBONELL \\ Profesor de Derecho Constitucional
}

\section{INTRODUCCIÓN ${ }^{1}$}

Cuando se cumplen veinte años de vigencia de la Constitución de 1978, al hablar de los derechos de los extranjeros se hace necesario abandonar la habitual y constante configuración de la extranjería como puro problema de politica migratoria y de control de flujos, para substituir esta concepción por otra más acorde con nuestro sistema consti- 
tucional de derechos. En efecto, ante el fenómeno de la emigración es posible la adopción de diversas opciones, las cuales deben en todo caso respetar las disposiciones constitucionales $y$, en especial, los efectos que derivan de la consideración constitucional de la dignidad de la persona y los derechos inviolables que le son inherentes, como fundamento del orden político y de la paz social (art. 10.1 CE). Además, las exigencias de interpretación de las normas relativas a derechos constitucionalmente reconocidos (art. 10.2 CE), imponen que cualquier regulación referida a los derechos de los extranjeros, tenga que ser interpretada de conformidad con la Declaración Universal de Derechos Humanos y los tratados o convenios ratificados por España.

Sin embargo, lejos de estas consideraciones, el tratamiento que recibe de hecho la extranjería ${ }^{2}$, se suele situar más en conexión con la denominada razón de Estado, el problema de la escasez o las diferencias culturales e ideológicas. Como bien puede fácilmente advertirse, tales consideraciones no constituyen justificaciones 0 argumentos constitucionales alegables desde una perspectiva jurídica. Sin embargo, de hecho, se imponen, originando la negación, a veces sistemática, del ejercicio de derechos constitucionales a ciertas personas, sencillamente por la única razón de ser extranjeros.

Por consiguiente, vamos a tratar de situar las coordenadas constitucionales en las que creemos debe enmarcarse la actuación pública en relación con los extranjeros. Pero, sobre todo, nos interesa enjuiciar el tratamiento, tanto legislativo como jurisprudencial, que ha venido

2 El tratamiento de la extranjería como un mero asunto de política migratoria ha sido una constante, no sólo en España sino en prácticamente todos los Estados de la Unión Europea. En el mismo derecho comunitario la categoría jurídica de extranjero proveniente de países terceros, origina situaciones altamente discriminatorias que conducen con frecuencia a la vulneración de otros tratados y obligaciones internacionales asumidas por los Estados miembros de la Unión, en especial el Convenio Europeo de Derechos Humanos y el Derecho Humanitario. En esta tónica, para el Tratado de Unión Europea, el extranjero no nacional de países miembros no existe: el art. 8 TEU (consolidado en el Tratado de Amsterdam) otorga los derechos comunitarios a los nacionales de los Estados miembros, y únicamente a ellos se les considera ciudadanos de la Unión. En la reforma operada a través del Tratado de Amsterdam los derechos de los extranjeros no han recibido mejor suerte. Sería deseable que, en momentos como los actuales, cuando está comenzando a estudiarse la ampliación de la Unión Europea, se avanzara hacia una Europa en la que, como mínimo, los extranjeros residentes en ella establecidos y que, en general, han ocupado con mejor o peor suerte los trabajos más ingratos $y$, a la vez, necesarios para la construcción de ese espacio común económico, dejaran de ser "ciudadanos de segunda", para pasar a tener un status jurídico asimilable al de la ciudadanía de la Unión. 
recibiendo el ejercicio de los derechos cuando sus titulares tienen como característica común la de no gozar de la nacionalidad ni española ni comunitaria europea.

\section{LOS DERECHOS DE LOS EXTRANJEROS EN LA CONSTITUCIÓN}

\section{Inserción de los derechos de los extranjeros en el marco general constitucional y su concreción a partir del art. 13 de la Constitución}

Cuando la Constitución regula los derechos de los extranjeros, ni alega la denominada razón de Estado ni subordina el ejercicio de los mismos a razones de índole económica. Salvo determinadas exclusiones de titularidad ${ }^{3}$, en el art. $13.1 \mathrm{CE}^{4}$ se afirma que los extranjeros go-

3 Si nos atenemos a una lectura lineal y aislada de los preceptos constitucionales, parece que la Constitución excluya explícitamente a los extranjeros de la titularidad de determinados derechos: la participación en los asuntos públicos y el acceso a las funciones y cargos públicos en condiciones de igualdad, con la excepción del sufragio activo y pasivo, que atendiendo a criterios de reciprocidad pueda establecerse por tratado o por ley, es un derecho que sólo se ha concedido a los extranjeros tras la reforma constitucional que se tuvo que realizar para ratificar el Tratado de Unión Europea (art. 13.2 en relación con el art. $23 \mathrm{CE}$ ). Por otra parte, la libertad de circulación y residencia (art. $19 \mathrm{CE}$ ), la igualdad ante la ley (art. $14 \mathrm{CE}$ ), el derecho de petición (art. $29 \mathrm{CE}$ ), el derecho y deber de defender a España (art. 30 $\mathrm{CE}$ ), el deber de trabajar y derecho al trabajo (art. $35.1 \mathrm{CE}$ ) y el derecho a disfrutar de una vivienda digna y adecuada (art. $47 \mathrm{CE}$ ), son configurados en estos artículos de la Constitución de tal forma que parecen excluir explícitamente que los extranjeros puedan ser titulares de tales derechos.

En todos los demás casos, tal como dispone el art. $13 \mathrm{CE}$, los extranjeros gozarán en España de las libertades públicas que garantiza el presente Título (el Título l) en los términos que establezcan los tratados y la ley. Como consecuencia, los tratados y la ley podrán determinar, ya veremos con qué limites, las peculiaridades del ejercicio de los derechos cuando su titularidad recaiga sobre personas extranjeras; pero tal regulación únicamente podrá establecer el régimen de ejercicio de los derechos, no excluir titularidades ni restringir el ámbito constitucional de los mismos en forma que haga impracticable su ejercicio a quienes no sean nacionales españoles. Incluso, como veremos posteriormente, es posible una ampliación de la titularidad de determinados derechos cuando así lo impongan los tratados internacionales.

Por último, señalaremos que en la Constitución aparece un derecho, el de asilo, reservado únicamente a los no nacionales españoles (art. 13.4 CE), cuya titularidad, en consecuencia, únicamente corresponde a los extranjeros y apátridas.

4 Artículo 13 de la Constitución española:

“1. Los extranjeros gozarán en España de las libertades públicas que garantiza el presente Título en los términos que establezcan los tratados y la ley. 
zarán en España de las libertades públicas que garantiza el presente Título en los términos que establezcan los tratados y la ley. Además, como ya hemos indicado, en el art. 10.2 CE se dispone que las normas relativas a los derechos fundamentales y a las libertades que la Constitución reconoce se interpretarán de conformidad con la Declaración Universal de Derechos Humanos y los tratados y acuerdos internacionales sobre las mismas materias ratificados por España, por lo que el contenido del art. 13.1 CE que acabamos de señalar, tendrá que ser interpretado conformemente a las exigencias del citado art. 10.2 de la Constitución.

Por consiguiente, a partir de lo que, en conjunto, disponen estas disposiciones constitucionales, podemos deducir:

a) Que las normas sobre derechos de los extranjeros, desde la Constitución hasta el último acto administrativo con valor normativo, deben ser necesariamente interpretadas de conformidad con la Declaración Universal y los tratados o acuerdos internacionales sobre derechos humanos ratificados por España. Estos textos internacionales contribuirán a determinar la configuración constitucionalmente adecuada de los derechos puesto que, los tratados o acuerdos ratificados, proporcionarán la medida o canon de constitucionalidad necesaria para que la interpretación de los derechos se ajuste a las previsiones de la Constitución ${ }^{5}$.

b) Que los extranjeros, de acuerdo con el criterio interpretativo anterior, serán titulares de los derechos que la Constitución no reserve en exclusiva a los españoles y de los derechos cuya titularidad pueda serles otorgada a partir de la Declaración Universal y los tratados ratificados por España. En este punto cabe destacar, entre los tratados ratificados por España, el Convenio Europeo de Derechos Humanos (también publicado oficialmente $y$, consiguientemente, teniendo valor de norma interna española a tenor del art. 96.1 CE) obliga a los Estados signatarios a reconocer los derechos regulados por el Convenio a toda

2. Solamente los españoles serán titulares de los derechos reconocidos en el artículo 23, salvo lo que atendiendo a criterios de reciprocidad, pueda establecerse por tratado o ley para el derecho de sufragio activo y pasivo en las elecciones municipales."

(El artículo $23 \mathrm{CE}$ se refiere al derecho al sufragio y al acceso a cargos y funciones públicas en condiciones de igualdad.)

5 Para el Tribunal Constitucional los tratados internacionales determinan los contenidos de los derechos, otorgándoles el "perfil exacto" querido por la Constitución (SSTC 28/1991 y 254/1993). 
persona sometida a su jurisdicción ${ }^{6}$. Por consiguiente, a los extranjeros que se encuentren sometidos a la jurisdicción española, se les debe necesariamente reconocer, además de los derechos de la Constitución cuya titularidad no les esté vedada, los derechos que les atribuye el Convenio Europeo de Derechos Humanos. Por último, destacaremos la existencia de una cláusula semejante en el Pacto Internacional de Derechos Civiles y Políticos7.

c) Que con relación a los extranjeros, las leyes y los tratados determinarán el grado de goce o disfrute de sus derechos, es decir, las leyes y los tratados podrán regular su ejercicio por parte de extranjeros, y ello estableciendo los procedimientos que los hagan plenamente efectivos ${ }^{8}$. Concretamente, cabe destacar que los derechos que la Constitución configure como de ejercicio directo, no pueden ser sometidos a autorización en ningún caso, bien sean ejercitados por españoles o por extranjeros ${ }^{9}$. La Constitución posibilita, pues, únicamente, el establecimiento de peculiaridades o especialidades en el régimen de

6 El artículo 1 del Convenio Europeo de Derechos Humanos dispone que las Altas Partes Contratantes reconocen a toda persona dependiente de su jurisdicción los derechos y libertades definidos en el título I del Convenio. Esta disposición otorga efecto territorial al Convenio Europeo, sin que los Estados puedan distinguir entre sus nacionales y los extranjeros sometidos a su jurisdicción; la única excepción que en el texto del Convenio se realiza con respecto de los extranjeros se encuentra en el art. $16 \mathrm{CEDH}$ cuando éste autoriza que se puedan imponer restricciones a su actividad política.

7 El artículo 2 del Pacto Internacional de Derechos Civiles y Políticos obliga a los Estados signatarios a respetar y garantizar los derechos que en él se reconocen a todos los individuos que se encuentren en su territorio y estén sujetos a su jurisdicción, sin distinción alguna de raza, color, sexo, idioma, religión, opinión politica o de otra indole, origen nacional o social, posición económica, nacimiento o cualquier otra condición social.

8 El Tribunal Constitucional tiene sentada una ya ingente jurisprudencia acerca del desarrollo legislativo del ejercicio de los derechos. Desde sus comienzos define el ejercicio de los derechos como el establecimiento de los procedimientos y formalismos que se instrumentan para conseguir su eficacia (STC de 8 de abril de 1981), precisando también que el desarrollo legislativo de un derecho consiste en regularlo en términos que permitan su plena aplicabilidad y eficacia y que, en este sentido, los procedimientos previstos por el legislador deben conducir, con las debidas garantías, a que el derecho encuentre su plenitud (STC 160/1987).

9 Asi lo ha dispuesto el Tribunal Constitucional en la sentencia al recurso de inconstitucionalidad sobre la Ley de Extranjería. Para el TC, en esta sentencia, el ejercicio del derecho de reunión sin autorización constituye una facultad necesaria para que el derecho sea reconocible como pertinente al tipo descrito, de tal forma que si se somete a autorización administrativa su ejercicio (como asi realizaba la Ley de Extranjería) el pretendido derecho muda su naturaleza y no puede ser reconocido como tal (STC 115/1987, de 7 de julio). 
ejercicio de los derechos con relación a los extranjeros, sin que tales singularidades puedan restarles efectividad o eficacia.

d) Que el contenido constitucionalmente declarado de los derechos ${ }^{10}$ debe ser íntegramente respetado en todo caso, de tal forma que las limitaciones a su ejercicio que, fundamentadas en las singularidades que puedan derivar de la titularidad cuando ésta sea atribuida a extranjeros, nunca podrán desnaturalizar el derecho de que se trate, ni someterlo a límites tales que, obstaculizando el ejercicio del derecho, originen tales perturbaciones en el mismo que éste devenga impracticable ${ }^{11}$.

e) Que a los extranjeros les debe ser aplicado el régimen de garantías previsto constitucionalmente para los derechos ${ }^{12}$, sin que quepa al respecto introducir diferencias, en el grado de protección que tengan los derechos, derivadas de la configuración que adopte su titularidad. Los extranjeros, por consiguiente, gozarán del mismo régimen de garantías que los españoles, ya que las garantías constituyen un elemento configurador de los derechos constitucionales que no varía por razón de la nacionalidad de su titular.

f) Que, de la misma manera que cuando el titular de los derechos es un español, los extranjeros pueden sufrir limitaciones en el ejercicio de los derechos cuya titularidad les es constitucionalmente

10 La utilización del concepto, "contenido constitucionalmente declarado» de los derechos fundamentales, que deriva del art. 55.1.a) de la Ley Orgánica del Tribunal Constitucional y el art. 7.2 de la Ley Orgánica del Poder Judicial, obedece a entenderla más afortunada, en el sentido de más explícita y más precisa y a los efectos del presente trabajo, que la del "contenido esencial" prevista por la Constitución.

11 Ésta ha sido la posición del Tribunal Constitucional, reiteradamente sostenida, desde la Sentencia de 8 de abril de 1991 (Recurso de Inconstitucionalidad contra determinados artículos del Decreto-Ley de 4 de marzo de 1977, regulador de la huelga y los conflictos colectivos de trabajo).

12 Especialmente destacaremos que nos referimos tanto a las garantías internas como internacionales, así como a las jurisdiccionales, institucionales, normativas o específicas. Es decir, no se puede restringir el régimen, nivel, standard o eficacia que tiene cada derecho, cuando su titular es un extranjero. Señalaremos al respecto que, en aplicación del Convenio Europeo de Derechos Humanos, la Comisión y el Tribunal de Estrasburgo han admitido reiteradamente denuncias contra Estados parte en el Convenio formuladas por extranjeros sometidos a la jurisdicción de los mismos. Así, por poner unos ejemplos, el Caso Abdulaziz, Cabales y Balkandali, Caso Berrehab, Caso Moustaquim, y otros que examinaremos al abordar la jurisprudencia del Tribunal Europeo sobre extranjeros. El efecto territorial del Convenio, en este sentido, otorga también a los extranjeros el acceso al régimen jurisdiccional de garantias previsto en el mismo. 
otorgada. Tales limitaciones, en aplicación de jurisprudencia absolutamente consolidada, deberán estar previstas en norma anterior, de rango y publicidad adecuados y suficientes, deberán ser necesarias en una sociedad democrática para perseguir una finalidad legítima y tendrán que ser proporcionales a las causas que las hayan originado ${ }^{13}$. Además, cualquier limitación a los derechos constitucionales, también según reiterada jurisprudencia, debe ser interpretada restrictivamente ${ }^{14}$.

g) Que, con relación a la posible suspensión de los derechos constitucionales derivada del art. $55 \mathrm{CE}$; la Constitución en ningún momento distingue entre suspensiones a nacionales o a extranjeros, por lo que hay que concluir que debe aplicarse el mismo régimen de suspensión, ya sea general o individualizada ${ }^{15}$, con independencia de

13 Para la determinación de los límites y para que éstos sean compatibles con las disposiciones constitucionales, hay que tener en cuenta el "test" elaborado por el Tribunal Europeo de Derechos Humanos y que también viene aplicando el Tribunal Constitucional a lo largo de prácticamente todas las sentencias en las que tiene entrar a examinar límites a los derechos. En este sentido, para que las limitaciones a los derechos sean legítimas es necesario: En primer lugar, que tales limitaciones hayan sido previstas en ley anterior, de suficiente rango según el derecho de qué se trate, y que haya podido ser conocida por sus destinatarios. En segundo lugar, las limitaciones deben ser necesarias para la defensa del derecho de que se trate en una sociedad democrática; necesidad que el Tribunal Europeo no identifica con oportunidad sino con justificación suficiente para conseguir finalidades legítimas; además el Tribunal de Estrasburgo, rechaza explícitamente, en reiterada jurisprudencia, que lo políticamente oportuno, pese a que los Estados gozan de cierto grado de discrecionalidad para interponer límites a los derechos, pueda ser identificado con lo necesario. $Y$ en tercer lugar, el limite debe cumplir con el requisito de proporcionalidad entre el fin legítimamente perseguido con su interposición y las causas que lo determinaron.

Esta interesante jurisprudencia sobre los límites puede verse, entre otras en las sentencias Caso Handyside, Caso Klass y otros, Caso Sunday Times, Caso Dudgeon, Caso Ciulla, destacando las más conocidas.

14 La interpretación restrictiva de los límites a los derechos también tiene su origen en la jurisprudencia del Tribunal Europeo de Derechos Humanos (Caso Ciulla), habiendo sido seguida también por parte del Tribunal Constitucional español en prácticamente toda su jurisprudencia. El Tribunal de Justicia de las Comunidades Europeas insiste también en la interpretación restrictiva de los límites a los derechos (ver, por todas, Caso Johnston, de 15 de mayo de 1986).

15 Recordaremos al respecto que, con relación a la suspensión general de derechos, debe ser previamente declarado el estado de excepción o de sitio (art. $55.1 \mathrm{CE})$, sin que en la Constitución se establezcan posibilidades especiales de suspensión o suspensiones a personas concretas. Y que, con relación a la suspensión individualizada, la cual sí recae en individuos determinados, los extranjeros no aparecen como sujetos pasivos distintos de los españoles respecto de tal suspensión, puesto que la Constitución la prevé para personas determinadas en relación con las investigaciones correspondientes a la actuación de bandas armadas o elementos terroristas (art. 55.2 CE). 
la nacionalidad. Los extranjeros no pueden estar sometidos, en consecuencia, a suspensiones de derechos no previstas para los españoles.

Las previsiones del artículo $13 \mathrm{CE}$, no deben pues interpretarse como habilitación al legislador o a la autoridad administrativa para limitar los derechos de los extranjeros por el simple hecho de no ser españoles, sino como un mandato constitucional dirigido a organizar, tanto por vía legislativa ordinaria como administrativa, el régimen del ejercicio de los derechos, estableciendo los cauces adecuados para que los extranjeros puedan ejercer sus derechos constitucionales en toda su plenitud, pudiendo en todo caso establecerse peculiaridades en su ejercicio, pero en modo alguno desconocerlos $u$ originar su ineficacia. El ejercicio de los derechos por parte de personas extranjeras no puede, pues, tomar como único referente las coordenadas propias de las denominadas politicas migratorias, puesto que la Constitución, en el Título 1 , dedicado a los derechos y deberes fundamentales, afirma que los extranjeros tienen derechos, precisamente los garantizados en el citado Título, y que gozarán de los mismos de conformidad con lo que establezcan los tratados y la ley.

Sin embargo, es necesario señalar que, pese a que las disposiciones constitucionales no distinguen en ningún momento entre españoles y extranjeros, la Ley Orgánica 4/1981, reguladora de los estados de alarma, excepción y sitio, de 1 de junio, instaura unas medidas especiales para los extranjeros. En esta ley se dispone que los extranjeros que se encuentren en España vendrán obligados a realizar las comparecencias que se acuerden, a cumplir las normas que se dicten sobre renovación o control de permisos de residencia y cédulas de inscripción consular y a observar las demás formalidades que se establezcan, pudiendo ser expulsados en caso de que no cumplan con las medidas especiales que se puedan adoptar cuando se declaren estados de excepción o de sitio (arts. 24 y 32.3 LOEAES). Contiene esta norma, como puede fácilmente apreciarse, una habilitación genérica e indeterminada a la autoridad gubernativa para que dicte discrecionalmente las medidas que considere oportunas. Tales medidas, por una parte, al afectar a la documentación ( «renovación o control de permisos de residencia y cédulas de inscripción consularn) que deben poseer los extranjeros para que su situación jurídica en España se encuentre dentro de la legalidad $y$, por otra parte, al venir éstos obligados a cumplir cualquier disposición que se dicte ("las demás formalidades que se establezcan'), se sitúan en el terreno de la más pura inseguridad jurídica y pueden originar verdaderas alteraciones en los derechos de los extranjeros que pueden constituir suspensiones de derechos no previstas constitucionalmente. Esta Ley, que hasta el presente (y esperemos que por mucho tiempo) no ha sido todavia aplicada, sólo sitúa en régimen de igualdad con los españoles a los apátridas y refugiados respecto de los cuales no sea posible la expulsión (art. 24.3) quebrantando de esta manera lo dispuesto en el art. 55.1 CE, que en ningún supuesto distingue entre españoles y extranjeros. 
Por consiguiente, la Constitución, lejos de presentar los derechos de los extranjeros como resultado de las políticas públicas que puedan ponerse en práctica por razones coyunturales o estructurales, los consolida como verdaderos derechos atribuidos a un colectivo concreto, las personas físicas que no tengan nacionalidad española, cuyo ejercicio puede ser que necesite de ciertas peculiaridades, pero que no puede serles negado en modo alguno, salvo en los supuestos en que la misma Constitución atribuya la titularidad concreta de un derecho únicamente a los españoles.

\section{Los condicionantes constitucionales de las políticas públicas en materia de extranjería}

Acabamos de examinar cómo la Constitución permite que los extranjeros sean titulares de ciertos derechos $y$, al mismo tiempo, les excluye de la titularidad de otros, como es el caso de la igualdad ante la ley, la entrada y salida de España, la libertad de circulación y residencia, el sufragio activo y pasivo ${ }^{16}$, el acceso a funciones y cargos públicos en condiciones de igualdad, el derecho de petición, el derecho y deber de defender a España, el deber de trabajar y el derecho al trabajo y el disfrute de una vivienda digna y adecuada,

En estos últimos supuestos, y únicamente en ellos, al no estar configurados por la Constitución como derechos cuya titularidad alcance a los extranjeros (porque el texto constitucional se refiere expresamente a los españoles), las situaciones jurídicas de los extranjeros aparecen como bienes jurídicos a proteger, es decir, como intereses sociales dignos de protección jurídica, cuya juridificación puede adoptar diversas manifestaciones, pero no como derechos fundamentales. En este sentido, en tales casos, las situaciones jurídicas de los extranjeros aparecen, a su vez, como bienes jurídicos disponibles en el marco de las distintas políticas públicas (políticas migratorias, políticas de empleo, etc.) a emprender por los poderes públicos en el marco de sus respectivas competencias y en relación con criterios de política social y económica. Y ello porque la Constitución ha incorporado estos bienes jurídicos otorgándoles una estructura de derecho subjetivo únicamente para los españoles, sin que tal estructura de derecho subjetivo fuera

16 Salvo en los supuestos antes mencionados de las elecciones municipales. 
prevista por la Constitución con relación a tales bienes jurídicos cuando sus titulares fueran extranjeros.

No obstante, en tales supuestos, las distintas políticas públicas que puedan emprenderse, han de situarse dentro del marco general constitucional, sin que puedan ser quebrantadas en ningún caso las normas constitucionales que puedan incidir en su ámbito de acción. En consecuencia, las distintas políticas públicas relativas a aquellos bienes jurídicos (es decir cuando no tenemos la cobertura de la configuración como derechos subjetivos) no podrán contrariar, ni por acción ni por omisión ${ }^{17}$, ninguna de las directrices, orientaciones, mandatos, procedimientos, etc. que puedan desprenderse del marco general constitucional o de cualesquiera regulaciones constitucionales concretas ${ }^{18}$.

\section{LOS DERECHOS DE LOS EXTRANJEROS EN LA JURISPRUDENCIA DEL TRIBUNAL EUROPEO DE DERECHOS HUMANOS ${ }^{19}$}

\section{Los derechos de los extranjeros en el Convenio Europeo de Derechos Humanos}

El artículo 1 del Convenio Europeo dispone que las Altas Partes Contratantes reconocen a toda persona dependiente de su jurisdicción

17 Las violaciones a los derechos pueden estar originadas por actos o por omisiones. Así lo afirma el Tribunal Europeo de Derechos Humanos en reiterada jurisprudencia (ver, por todas, Caso Plattform "Arzte für das Leben»). El Tribunal Constitucional también ha reconocido insistentemente que pueden existir violaciones de los derechos fundamentales por la inacción de los poderes públicos, habiéndose incluso pronunciado en favor de la denominada inconstitucionalidad por omisión, la cual se origina cuando el legislador debía promulgar una norma prevista por la Constitución como desarrollo del ejercicio de un derecho y no ha cumplido con tal mandato (ver STC 281/1994, de 17 de octubre).

18 No son éstos los únicos condicionantes de las políticas de extranjería. Los tratados internacionales ratificados y/o oficialmente en España también inciden directamente en los derechos de los extranjeros, siendo necesario determinar cuáles son los condicionantes que tales normas internacionales imponen tanto a la regulación normativa interna de los derechos de los extranjeros como a las políticas de extranjería.

19 En el presente trabajo abordamos los criterios interpretativos que, vía artículo 10.2 CE, producen las sentencias del Tribunal Europeo de Derechos Humanos en materia de derechos de los extranjeros. Ello no obstante, es necesario aludir también, siquiera en esta nota, a los Tratados Comunitarios, tanto por constituir tratados de ámbito de europeo y por las exigencias de su aplicabilidad como normas 
los derechos y libertades definidos en su Título l, otorgando de esta forma al Convenio una efectividad o alcance territorial ${ }^{20}$.

El Convenio Europeo, además, o bien reconoce los derechos a "toda persona" o bien prohíbe que "nadie" padezca determinadas vejaciones, con lo que se entiende que los derechos reconocidos en el mismo afectan por igual a toda persona que se halle bajo la jurisdicción de cualquiera de los Estados signatarios, tenga o no la nacionalidad del mismo. Además, la única referencia que en el texto del Convenio se realiza con respecto de los extranjeros se encuentra en el art. $16 \mathrm{CEDH}^{21}$ cuando éste autoriza que se puedan imponer restricciones a su actividad política.

Por otra parte, en el mismo texto del Convenio, en el artículo 14, se establece la igualdad y la prohibición de discriminación por razón de, entre otras, origen nacional22. Los Estados signatarios no pueden,

de derecho interno derivadas del mandato del art. $96.1 \mathrm{CE}$, así como por el hecho de configurar un órgano jurisdiccional de garantía como es el Tribunal de Justicia de las Comunidades Europeas.

Ciertamente, el Derecho Comunitario se ha ocupado en determinados supuestos por los derechos de los extranjeros, pero su ámbito de actuación preferente ha sido el de los problemas derivados de la igualdad de trato entre los ciudadanos comunitarios frente a todos los Estados de la Unión. Existen, sin embargo, determinadas regulaciones, como las de los Acuerdos de Shengen y el acervo de ellos derivado, que inciden directamente sobre los ciudadanos provenientes de terceros paises que pretenden ingresar en el territorio europeo y que regulan con detalle las condiciones de entrada, salida y circulación de los extranjeros extracomunitarios en Europa. Al respecto hemos de señalar que no existen pronunciamientos del Tribunal de Justicia en esta materia puesto que en los Acuerdos y en el Tratado para la Unión Europea se habían excluido tales asuntos de la competencia del mencionado Tribunal y que cuando entre en vigor el Tratado de Amsterdam el Tribunal de Justicia sí tendrá competencia acerca de los derechos afectados por el acervo de Shengen.

Ello no obstante, dada la situación juridica actual y para no extralimitar el ámbito del trabajo que presentamos, vamos a dejar de lado estas regulaciones, aunque señalamos su importancia para situar jurídicamente los derechos de entrada, salida, circulación y residencia en España, como Estado integrado en la red Shengen.

20 Artículo 1 del Convenio Europeo: "Las Altas Partes Contratantes reconocen a toda persona dependiente de su jurisdicción los derechos y libertades definidos en el título I del presente Convenio."

21 Artículo 16 del Convenio Europeo: «Ninguna de las disposiciones de los artículos 10, 11 y 14 podrá ser interpretada en el sentido de que prohíbe a las Altas Partes Contratantes imponer restricciones a la actividad política de los extranjeros."

(El artículo 10 del Convenio se refiere a la libertad de expresión e información, el art. $11 \mathrm{CEDH}$ a la libertad de reunión y asociación y el art. $14 \mathrm{CEDH}$ a la igualdad y no discriminación.)

22 Artículo 14 del Convenio Europeo: «El goce de los derechos y libertades reconocidos en el presente Convenio ha de ser asegurado sin distinción alguna, es 
en consecuencia, introducir diferencias de trato entre nacionales y extranjeros, que vulneren el principio general de igualdad que deriva de la interpretación sistemática de los derechos garantizados por el Convenio Europeo ${ }^{23}$.

El Tribunal Europeo, en varias de sus sentencias reafirma lo dispuesto por el Convenio e, incluso, va más allá de lo que éste regula expresamente respecto de la extensión de los derechos a los extranjeros. Así, del mismo modo que acepta sistemáticamente las demandas contra cualquier Estado signatario del Convenio por parte de quien esté sujeto a su jurisdicción, con independencia de la nacionalidad del demandante, el TEDH configura el alcance concreto que, en cada caso, obtienen los derechos cuya violación se denuncia.

\section{La competencia del Tribunal Europeo de Derechos Humanos para entender de asuntos contra Estados integrados en el Consejo de Europa cuando las demandas son presentadas por ciudadanos extranjeros}

Después de casi cuatro décadas de actuación, el Tribunal Europeo de Derechos Humanos no ha puesto ningún tipo de objeción a las demandas reenviadas por la Comisión o por alguno de los Estados signatarios del Convenio, cuando habían sido interpuestas ante la Comisión Europea por personas no nacionales del Estado demandado. Del examen del conjunto de sus sentencias se reafirma, pues, la extensión de las garantías del Convenio Europeo a cualquier persona que se encuentre bajo la jurisdicción de cualquier Estado signatario del mismo.

pecialmente por razones de sexo, raza, color, lengua, religión, opiniones políticas u otras, origen nacional o social, pertenencia a una minoría nacional, fortuna, nacimiento o cualquier otra situación".

23 También hay que señalar que el Convenio Europeo de Derechos Humanos no se agota con el texto de su articulado, puesto que le han sido adicionados una serie de Protocolos entre los cuales destacaremos, pese a no haber sido ratificado por España (con todos los inconvenientes para los derechos de los extranjeros se derivan de la falta de adhesión a tal Protocolo) el Protocolo n..$^{\circ}$, de 22 de noviembre de 1984, que se refiere al ejercicio de determinados derechos por parte de extranjeros que se hallen en el territorio de los Estados signatarios del mismo. Concretamente, en este Protocolo se instrumentan garantías jurídicas que deben ser aplicadas en los procedimientos de expulsión de extranjeros. 
Por poner unos ejemplos podemos citar el Asunto McGoff (ciudadano irlandés) contra el Reino de Suecia en reclamación relativa al derecho a la libertad personal, Asunto Pakelli (ciudadano turco) contra la República Federal Alemana alegando violación del derecho a un juicio equitativo, el Asunto $O$ contra el Reino Unido (ciudadano irlandés) en un supuesto relacionado con la protección a la familia, el Asunto Sramek (ciudadana estadounidense) contra la República Federal Alemana en cuestiones relacionadas con el acceso a la propiedad y el derecho a un tribunal independiente e imparcial. Durante el presente año, el TEDH ha pronunciado también las sentencias al Asunto Soumare (ciudadano de Mali) contra Francia acerca del derecho a un recurso cierto y eficaz para controlar la legalidad de las detenciones y al Asunto Erkalo (ciudadano etíope) reiterando que la obligación de verificar que los controles judiciales para que la denegación de la puesta en libertad de los enfermos mentales condenados se realice dentro de los plazos legalmente establecidos, corresponde a las autoridades nacionales y no a los sujetos recluidos.

A mayor abundamiento señalaremos también los casos contra España en los que los demandantes no eran ciudadanos españoles, como son el Asunto Van der Tang (ciudadano holandés) y el Asunto Scott (ciudadano británico) ambos abordando el tema de la duración de la prisión provisional.

En todos estos casos, el fondo del litigio consiste en determinar si existe o no violación de los derechos del Convenio y ello con independencia de la nacionalidad del recurrente.

\section{Los criterios de interpretación del Tribunal Europeo de Derechos Humanos sobre los derechos de los extranjeros}

Sentado el principio de la aplicación territorial del Convenio Europeo y de su interpretación por parte del Tribunal Europeo de Derechos Humanos, es necesario concretar en qué manera interpreta este Tribunal los derechos cuando se encuentra frente a titulares extranjeros sujetos a las normas que, sobre extranjería o con relación a las políticas migratorias, rigen en los Estados miembros del Consejo de Europa. 
1. Con relación a la exigencia de igualdad y la prohibición de discriminación

El art. $14 \mathrm{CEDH}$ dispone que el goce de los derechos y libertades reconocidos en el Convenio ha de ser asegurado sin distinción alguna, especialmente por razones de sexo, raza, color, lengua, religión, opiniones políticas u otras, origen nacional o social, pertenencia a una minoria nacional, fortuna, nacimiento o cualquier otra situación. Hay que advertir al respecto que, con relación a este artículo 14, la versión francesa e inglesa del Convenio, que son las oficiales, no coinciden: la versión francesa dispone que el goce de los derechos ha de reconocerse "sans distinction aucune" (texto que impone la igualdad de trato), mientras que la versión inglesa afirma que tal goce ha de asegurarse "without discrimination" (admitiendo el trato distinto que no sea discriminatorio).

La discrepancia entre ambas versiones ha sido saldada por el Tribunal Europeo desde la primera sentencia en la que tuvo que abordar problemas en relación con el art. $14 \mathrm{CEDH}$, el Asunto del régimen de la lengua en Bélgica, disponiendo que la igualdad impuesta por el art. 14 CEDH tenía que interpretarse en el sentido de la versión inglesa, es decir, como prohibición de discriminación.

Con relación, pues, a los derechos de los extranjeros, el Tribunal Europeo ha aplicado el art. $14 \mathrm{CEDH}$ en diversas sentencias, adoptando los siguientes criterios jurisprudenciales:

A) Respecto de la igualdad entre mujeres y hombres el TEDH considera que las políticas migratorias, a los efectos de la concesión de los permisos de trabajo y residencia, han de regularse en condiciones de igualdad de derechos para ambos cónyuges:

Con relación a la igualdad entre mujeres y hombres y la prohibición de discriminación por razón de sexo, el Tribunal Europeo considera que el otorgamiento de permisos de entrada y residencia ha de realizarse en condiciones de igualdad entre hombres y mujeres en el caso de cónyuges de trabajadores extranjeros legalmente establecidos (Asunto Abdulaziz, Cabales y Balkandali contra el Reino Unido). 
En este caso las recurrentes, extranjeras que poseían permiso de trabajo y residencia en el Reino Unido, impugnaban la política migratoria de este país a partir de la cual, los extranjeros con residencia legal podían obtener el permiso de residencia de sus esposas, pero no se atribuia el mismo efecto a los permisos de residencia de extranjeras que pretendieran reunirse con sus esposos.

La base jurídica de la pretensión de las recurrentes se sitúa en el art. $8 \mathrm{CEDH}$ cuando éste impone el respeto a la vida privada y familiar ${ }^{24}$, en relación con el art. $14 \mathrm{CEDH}$ cuando éste prohíbe cualquier distinción por razón de origen nacional. El Gobierno del Reino Unido argumentaba que el Convenio Europeo no era aplicable a la política migratoria $y$, por lo tanto, que podía libremente decidir los supuestos en que fuera procedente la reunificación familiar.

El Tribunal Europeo, por su parte, afirma que, al garantizar el derecho al respeto a la vida familiar, el art. $8 \mathrm{CEDH}$ presupone la existencia de una familia, y que, si se trata de una pareja casada, la expresión vida familiar comprende normalmente la convivencia ${ }^{25}$. Por otra parte, el TEDH reconoce el derecho de los Estados a controlar la entrada de los no nacionales en su territorio. Debido a que las recurrentes entraron solteras en el Reino Unido y contrajeron matrimonio una vez establecidas legalmente en este país, el TEDH no considera que haya existido violación del derecho a la vida familiar del art. $8 \mathrm{CEDH}$. Conclusión que, sensu contrario, implicaría la existencia de violación del derecho al respeto de la vida familiar si las recurrentes hubieran estado casadas antes de establecerse legalmente en el Reino Unido.

\section{Artículo 8 del Convenio Europeo:}

«1. Toda persona tiene derecho al respeto de su vida privada y familiar, de su domicilio y de su correspondencia.

2. No podrá haber injerencia de la autoridad pública en el ejercicio de este derecho, sino en tanto en cuanto esta injerencia esté prevista por la ley y constituya una medida que, en una sociedad democrática, sea necesaria para la seguridad nacional, la seguridad pública, el bienestar económico del país, la defensa del orden y la prevención del delito, la protección de la salud o de la moral, o la protección de los derechos y libertades de los demás.”

${ }_{25}$ Invoca al respecto el Asunto Marckx contra los Países Bajos, en relación con las discriminaciones que originaba en Holanda la discriminación existente entre hijos nacidos de matrimonio legal e hijos que habian nacido sin existencia previa de matrimonio legal, los cuales tenían que ser adoptados para ser llamados a suceder e, incluso tras su adopción, sus derechos sucesorios eran distintos e inferiores a los hijos nacidos de matrimonio legal. El TEDH consideró discriminatoria esta diferencia de trato y equiparó a todos los hijos con independencia del estado civil de sus padres. 
Una vez descartada la vulneración del art. $8 \mathrm{CEDH}^{26}$, el Tribunal Europeo examina si ha podido existir discriminación a la luz del art. 14 CEDH. Para ello aplica el "test" de tres puntos que constituye una constante en la determinación de la doctrina del Tribunal Europeo acerca de la igualdad y no discriminación ${ }^{27}$. Tras afirmar que los Estados gozan de un cierto margen de discrecionalidad para regular la entrada de no nacionales en su territorio, el TEDH considera que en el Reino Unido era más fácil para un hombre extranjero que se hubiera establecido allí legalmente, obtener el permiso de residencia para su cónyuge no nacional, que si quien efectuaba tal solicitud se trataba de una mujer extranjera. Rechazando las tesis del Gobierno del Reino Unido respecto de la incidencia de la emigración en el mercado de trabajo, el TEDH afirma no estar convencido de que la diferencia de impacto en el mercado de trabajo originado por la entrada de emigrantes hombres o de emigrantes mujeres, pueda justificar una diferencia de trato como la que se deriva de las leyes de emigración que otorgan el permiso de residencia por reunificación familiar a las cónyuges femeninas pero no a los cónyuges masculinos, de trabajadores legalmente establecidos, por lo que concluye condenando al Reino Unido.

Como consecuencia, el Tribunal Europeo exige igualdad de trato entre hombres y mujeres a los efectos de la concesión de permisos de

26 Para el Tribunal Europeo el derecho a la igualdad carece de existencia independiente y no cabe alegarlo si no es con relación a otro de los derechos del Convenio (desde el Asunto Sindicato Nacional de la Policía Belga) el TEDH declara que el artículo $14 \mathrm{CEDH}$ forma parte integrante de todos y cada uno de los diversos artículos que garantizan los derechos y libertades, cualquiera que sea la naturaleza de estos últimos.

27 Como hemos señalado anteriormente, desde el Asunto del régimen de la lengua en Bélgica, el TEDH se inclina por la versión inglesa del texto oficial del Convenio, entendiendo igualdad como no discriminación y considerando, como consecuencia, que el art. $14 \mathrm{CEDH}$ no prohíbe toda diferencia de trato. Admitiendo, pues, que no todo trato diferente comporta violación del Convenio, puesto que únicamente es incompatible con el mismo aquel que implique trato discriminatorio, el TEDH considera que es necesario averiguar, en cada caso concreto, si la diferencia de trato viola o no el art. $14 \mathrm{CEDH}$. Para ello, ya en esta sentencia, sienta los criterios generales que permiten afirmar si existe o no trato discriminatorio, afirmando que:

1. La igualdad de trato queda violada cuando, entre casos comparables, la distinción carece de justificación objetiva.

2. La existencia de una justificación semejante debe apreciarse en relación con la finalidad de los efectos de la medida examinada en atención a los principios que generalmente prevalecen en las sociedades democráticas.

3. El art. 14 del Convenio también se ve violado cuando resulta que no existe una razonable relación de proporcionalidad entre los medios empleados y la finalidad perseguida. 
entrada y residencia para los cónyuges de trabajadores extranjeros legalmente establecidos.

B) Respecto de la prohibición de discriminación por razón de origen nacional:

En el art. $14 \mathrm{CEDH}$ se prohíbe la discriminación por razón de origen nacional. Ello ha sido interpretado por el Tribunal Europeo de Derechos Humanos en el sentido de que la igualdad garantizada por el Convenio no comporta trato idéntico entre nacionales extranjeros $\mathrm{ni}$ tampoco exige que siempre exista equiparación entre extranjeros nacionales de Estados miembros de la Unión Europea y extranjeros provenientes de terceros Estados (Asunto Moustaquim contra Bélgica, Asunto $C$ contra Bélgica y Asunto Gaygusuz contra Austria). En este sentido, el Tribunal Europeo afirma que:

- El Convenio no otorga igualdad absoluta de trato entre extranjeros de terceros Estados y extranjeros nacionales de Estados de la Unión Europea (Asunto Moustaquim y Asunto C., ambos contra Bélgica).

En ambos casos se discute si es compatible con el Convenio la legislación belga sobre expulsión de extranjeros cuando, para los provenientes de terceros Estados las condenas penales pueden justificar la expulsión mientras que, con relación a los extranjeros nacionales de otros Estados pertenecientes a la Unión Europea, una condena penal no basta para exponerlos a tal medida.

El Tribunal Europeo recuerda que el art. $14 \mathrm{CEDH}$ protege contra discriminaciones que afecten a individuos situados en condiciones análogas. Por otra parte, considera que puede darse un trato diferente a un menor delincuente belga con relación a un menor delincuente extranjero. Para el TEDH, Bélgica está sometida a un orden jurídico específico, como es el derivado de su pertenencia a la Unión Europea, y ello justifica que las normas belgas reguladoras de las expulsiones puedan otorgar un trato distinto a los extranjeros comunitarios y que los extranjeros provenientes de terceros Estados no gocen del mismo régimen de permanencia en el territorio. 
- El Convenio prohíbe que los extranjeros residentes legales sean discriminados con relación a los nacionales de un Estado en materia de prestaciones de la seguridad social (Asunto Gaygusuz contra Austria).

En este caso se trataba de una reclamación por denegación de la prestación por desempleo que la legislación austríaca subordinaba al pago previo de las contribuciones a la caja de seguro de desempleo. EI demandante, extranjero residente en Austria y que había cotizado a la seguridad social por el mismo concepto y sobre la misma basa que los nacionales austriacos, había visto denegada su petición exclusivamente por la comprobación de que no poseía la nacionalidad austriaca y no figuraba entre las personas dispensadas de cumplir esta condición.

Dado que la igualdad proclamada por el Convenio no tiene existencia independiente de los derechos que en aquél se reconocen, la discriminación alegada se basaba en la aplicación del art. 1.1 del Protocolo Adicional al Convenio Europeo, que dispone que toda persona física o moral tiene derecho al respeto de sus bienes. El contenido económico de las prestaciones por desempleo sitúan esta reclamación bajo el ámbito de la conexión entre el art. 14 CEDH y el art. 1.1 del Protocolo Adicional.

Para el TEDH el Sr. Gaygusuz, reuniendo las demás condiciones legales para la atribución de tal prestación, se encontraba en una situación análoga a la de los nacionales austríacos en cuanto a su derecho al seguro de desempleo, por lo que la falta de nacionalidad austríaca no comportaba una razón "objetiva y razonable» para justificar su exclusión de la prestación.

2. Con relación a las expulsiones o extradiciones a terceros países en los que existan indicios fundados de que la persona transferida pueda ver puesta en peligro su vida o ser objeto de tortura o tratos inhumanos o degradantes incompatibles con el convenio europeo

En varias sentencias, el Tribunal Europeo aplica el art. $3 \mathrm{CEDH}$, que prohíbe la tortura y los tratos inhumanos o degradantes ${ }^{28}$ para im-

28 El art. 3 CEDH dispone: gradantes."

"Nadie podrá ser sometido a tortura ni a penas o tratos inhumanos o de- 
pedir que puedan ser expulsadas o extraditadas aquellas personas que puedan ser objeto de tortura o tratos inhumanos o degradantes en los países de destino (Asunto Soering contra el Reino Unido, Asunto Cruz Varas contra Suecia, Asunto Chahal contra el Reino Unido, Asunto Ahmed contra Austria y Asunto H.R.L. contra Francia) ${ }^{29}$. El Tribunal Europeo ha establecido al respecto los siguientes criterios:

Este artículo no puede ser objeto de derecho de derogación por parte de los Estados signatarios del Convenio, ya que el art. $15 \mathrm{CEDH}$ establece que:

"1. En caso de guerra u otro peligro público que amenace la vida de la nación, cualquier Alta Parte Contratante podrá tomar medidas que deroguen las obligaciones previstas en el presente Convenio en la medida estricta en que lo exija la situación, siempre que tales medidas no estén en contradicción con las otras obligaciones que dimanan del derecho internacional.

2. La disposición precedente no autoriza ninguna derogación al artículo 2 , salvo en el caso de muertes resultantes de actos lícitos de guerra, y a los artículos 3,4 (párrafo 1) y $7 . "$

29 Hay que señalar en este punto que el TEDH ha emitido un pronunciamiento de archivo del caso en el Asunto Ali contra Suiza, puesto que en los procedimientos judiciales internos se acordó la libertad del demandante, sujeto a arresto administrativo en espera de expulsión, y éste desapareció sin acudir personalmente en el procedimiento iniciado ante el TEDH.

Existe otro caso ante el TEDH, el Asunto Bahaddar contra los Países Bajos, en el que el Tribunal Europeo tampoco se pronuncia sobre el fondo del asunto por no haberse agotado los recursos internos. Ello no obstante, en este caso hay que destacar que el TEDH considera que cuando se intente la obtención del estatuto de refugiado político, en los recursos contra la decisión denegatoria es necesario establecer plazos lo suficientemente amplios como para que el interesado pueda aportar la justificación de sus alegaciones.

Cabe hacer mención también, pese a que el TEDH no entró en el fondo por concluir con arreglo amistoso, el Asunto B.B. contra Francia, en el que tras haber emitido la Comisión Europea su dictamen considerando que había existido violación del Convenio, los jueces nacionales anularon una decisión de expulsión sobre un ciudadano del Congo por razones de salud. El demandante había visto denegada su petición de asilo político (su padre había sido ejecutado por orden de Mobutu y sus cuatro hermanos tenían el estatuto de refugiado político, dos en Francia y otros dos en Bélgica) y, tras ser condenado por posesión de drogas y por haber efectuado entradas y salidas irregulares de Francia, era objeto de una orden de expulsión. Constatado judicialmente que estaba siguiendo un tratamiento médico por haber contraido el sida y que, de hacerse efectiva la expulsión, la interrupción de tal tratamiento disminuiría efectivamente su esperanza de vida, los tribunales internos decidieron anular la expulsión y acordar una asignación de residencia con la obligación de solicitar permiso para los desplazamientos y de presentarse con regularidad ante las autoridades administrativas. Tal decisión judicial, para el TEDH constituye título suficiente para considerar que, mientras los hechos no cambien, ha desaparecido la posibilidad de violación de los derechos del Convenio y, como consecuencia, no emitió sentencia sobre el fondo al respecto. 
- Los Estados no pueden otorgar una extradición cuando de ella pueda derivarse violación del art. 3 del Convenio (Asunto Soering contra el Reino Unido y Asunto Cruz Varas contra Suecia).

En el primer caso, el Asunto Soering, el Tribunal Europeo se enfrentaba a la interpretación del art. $5 \mathrm{CEDH}$, cuando éste autoriza la detención de una persona contra la que se sigue un procedimiento de extradición, en relación con el art. $3 \mathrm{CEDH}$, que prohíbe los tratos inhumanos y degradantes.

Tras recordar que el art. 3 CEDH no puede ser objeto de derogación en ningún caso ${ }^{30}$, el TEDH afirma que, pese a que el Convenio no consagra un derecho a no ser extraditado, del mismo Convenio se deduce una obligación implícita de no extraditar en el caso de que el fugitivo corra el riesgo de sufrir en el Estado de destino penas o tratamientos inhumanos o degradantes.

Siguiendo esta jurisprudencia, pero en sentido contrario, en el Asunto Cruz Varas contra Suecia, en cual el Tribunal Europeo no consideró probado que el extraditado pudiera estar expuesto a tales situaciones, el TEDH concluyó que no se violaba el Convenio concediendo una extradición que no conllevara el peligro de ser sometido a penas o tratos inhumanos o degradantes en el país de destino.

- Los Estados no pueden expulsar a una persona que corra peligro real de ser sometida a malos tratos en el país de destino, aunque la expulsión estuviera motivada en razones de seguridad nacional (Asunto Chahal contra el Reino Unido).

A diferencia del supuesto anterior en el que se analizaban extradiciones, el Tribunal Europeo aborda el supuesto de la expulsión hacia la India de una persona perteneciente a la comunidad Sikh en cuyo seno ocupaba un cargo notorio.

EI TEDH, tras destacar que ni el Convenio ni sus Protocolos consagran el derecho al asilo político considera, de otro lado, que el art. 3 CEDH no prevé restricción alguna a su aplicación y que, aún por razo-

30 El art. $15 \mathrm{CEDH}$, que permite que los Estados puedan derogar las garantias del Convenio, dispone que en ningún caso pueda quedar derogada la prohibición de la tortura y de los tratos inhumanos o degradantes. 
nes de seguridad nacional, especialmente la lucha contra el terrorismo, este art. 3 no sufre ninguna excepción, incluso en caso de peligro público que amenace la vida de la nación.

Para resolver el caso el TEDH examina cual es la situación en el Pendjab y las garantías ofrecidas por el Gobierno de la India, constatando que la policía del Pendjab tenía por hábito actuar sin respetar los derechos humanos de los Sikhs, que se perseguía a las personas que buscaban refugio en regiones indias alejadas del Pendjab, así como que no existían pruebas concretas relativas a una reforma o una reorganización profunda de la policía del Pendjab para garantizar los derechos humanos en sus acciones. EI TEDH no se convence de que las seguridades ofrecidas por el Gobierno de la India con relación a la seguridad del Sr. Chahal, estimando que la notoriedad del mismo tiende a aumentar los peligros que corre. En consecuencia, el TEDH considera acreditado que el Sr. Chahal se arriesga realmente a sufrir malos tratos contrarios al artículo $3 \mathrm{CEDH}$ si es devuelto a la India.

Como consecuencia de estas consideraciones, el TEDH considera que si esta expulsión fuera ejecutada se produciría una violación del art. 3 del Convenio Europeo.

- El análisis de las circunstancias que justifican la no expulsión de un extranjero acogido al derecho de asilo y condenado judicialmente, han de apreciarse con relación a la situación existente en el país de destino en el momento de la expulsión (Asunto Ahmed contra Austria).

En este asunto se trataba de examinar si una persona que gozaba del estatuto de refugiado político, podía ser expulsada a Somalia por razón de haber sido condenado penalmente.

EI TEDH consideró que expulsión de un extranjero puede implicar la violación del Convenio cuando existen motivos serios y acreditados para creer que el interesado, si se le expulsa hacia el país de destino, correrá allí un riesgo real de ser sometido a un tratamiento contrario al art. $3 \mathrm{CEDH}$. En estos casos, para el TEDH, el comportamiento de la persona, aún cuando fuere considerado inaceptable o peligroso, no es razón que justifique su expulsión.

Para determinar si existe o no tal peligro, el TEDH afirma que si bien es cierto que los hechos históricos (es decir, aquéllos que justificaron la concesión del estatuto de asilado) presentan interés en la me- 
dida en que permiten aclarar la situación actual y su probable evolución, son las circunstancias presentes las que resultan determinantes.

De esta manera, la situación en Somalia al momento de pronunciarse la sentencia del Tribunal Europeo, no había cambiado significativamente, puesto que el país seguía en guerra civil y nada indicaba que los peligros que corría el Sr. Ahmed en el pasado hubieran dejado de existir. Como consecuencia, de producirse efectivamente su expulsión hacia Somalia, se violaria el art. 3 del Convenio.

- No se puede expulsar a un extranjero enfermo de sida terminal aunque haya sido condenado penalmente (Asunto D. contra el Reino Unido).

El Tribunal Europeo ha considerado dentro del ámbito del art. 3 CEDH la orden de expulsión de un enfermo terminal de sida originario de Saint-Kitts (Caribe oriental). En este supuesto se trataba de un extranjero condenado penalmente por narcotráfico que, en el momento de la orden de expulsión, tenia una esperanza de vida muy reducida aún cuando pudiera continuar con el tratamiento que una organización humanitaria le proporcionaba en el Reino Unido. Por añadidura, para el TEDH nada probaba que el enfermo pudiera continuar su tratamiento en el pais de destino ni que su familia de alli (un primo) estuviera dispuesta a acogerlo.

De efectuarse la expulsión, según la sentencia del TEDH, se produciría una violación del Convenio ya que, a pesar de que los Estados tienen derecho a expulsar a los extranjeros delincuentes, la situación en que se encontraria el demandante podría ser considerada como un tratamiento inhumano y degradante a la luz del art. $3 \mathrm{CEDH}$. Conteniendo, como lo hace este artículo, una prohibición de carácter absoluto, el TEDH concluye la necesidad de no ejecutar la orden de expulsión.

- La prohibición de expulsar cuando se temen tratos inhumanos o degradantes en el país de destino también actúa cuando el peligro proviene de la existencia de organizaciones criminales y no de la actuación de las autoridades públicas (Asunto H.L.R. contra Francia).

En el Asunto H.L.R. contra Francia, el Tribunal Europeo se pronunció acerca de la expulsión de un colombiano condenado por narcotráfico que había cooperado con las autoridades francesas denuncian- 
do a sus cómplices. El demandante alegaba que como consecuencia, si era expulsado a Colombia corría serio riesgo de ser objeto de represalias por parte de sus antiguos compañeros.

Frente a las argumentaciones del Gobierno de Francia, que alegaba que, al no provenir de las autoridades colombianas el peligro de malos tratos, no se estaba dentro del ámbito de aplicación del art. 3 CEDH, el Tribunal Europeo consideró que este artículo también era de aplicación cuando el riesgo de tratos inhumanos o degradantes no proviene de las autoridades públicas. Sentada esta afirmación, para el TEDH, en estos casos para que el art. 3 del Convenio actúe impidiendo la expulsión, es necesario demostrar que las autoridades del país de destino son incapaces de asegurar una protección efectiva.

En el supuesto concreto que comentamos, el TEDH considera que el demandante no ofrece argumentos suficientes que lleven a la conclusión de que las autoridades de su país no puedan asegurarle tal protección $y$, en consecuencia, que la expulsión no viola el art. 3 del Convenio. Por el contrario, la argumentación del Tribunal Europeo conduce a la consideración de que si el demandante hubiera probado la veracidad de sus afirmaciones, la orden de expulsión si hubiera violado las garantías ofrecidas por el art. $3 \mathrm{CEDH}$. En consecuencia, este artículo 3 del Convenio se aplica también a las posibles violaciones efectuadas por particulares e impide que en tales casos puedan considerarse legítimas las expulsiones de extranjeros.

\section{Con relación a la protección de la vida familiar de personas extranjeras}

El derecho a la protección de la vida familiar se encuentra garantizado por el articulo 8 CEDH y, en aplicación del criterio de territorialidad que impone el art. $1 \mathrm{CEDH}$, los extranjeros que se hallen en cualquier Estado parte en el Convenio, gozan también de la titularidad de este derecho. Sin embargo, su ejercicio puede estar condicionado por las políticas migratorias definidas por los Estados siempre que estas limitaciones estén previstas por la ley, estén justificadas objetiva y razonablemente para cumplir finalidades legítimas y sean proporcionadas a las circunstancias que originaron su adopción ${ }^{31}$. Varias sentencias del

31 El Tribunal Europeo ha configurado un escrutinio o "test» que debe ser respetado en los supuestos en que los Estados, dentro del margen de apreciación 
Tribunal Europeo de Derechos Humanos (Asunto Berrehab contra los Países Bajos, Asunto Moustaquim contra Bélgica, Asunto Beljoudi contra Francia, Asunto Nasri contra Francia, Asunto Gül contra Suiza, Asunto C. contra Bélgica y los Asuntos Bouchelkia, Mehemi, El Boujaidi, Boujlifa y Dalia, todos contra Francia) analizan diversas cuestiones relacionadas con el derecho a la protección de la vida familiar, tanto en relación con el derecho de reagrupación familiar y de la unidad de la familia, como con su compatibilidad con las expulsiones decretadas por los Estados. Los criterios que consideramos más importantes al respecto son:

a) Respecto del derecho a la reagrupación familiar el TEDH considera que hay que encontrar un justo equilibrio entre los intereses de los individuos y los de la sociedad en general (Asunto Gül contra Suiza).

Se trata, en estos supuestos, de conseguir que un extranjero consiga reagrupar en su país de residencia, a determinados miembros de su familia que permanecen en su pais de origen.

El Tribunal Europeo analiza este derecho en relación con el art. 8 del Convenio, cuando éste es alegado por personas que no tienen la nacionalidad del Estado signatario en el Asunto Gül contra Suiza, en el que se trata de decidir si un matrimonio que tiene un permiso no permanente de residencia, concedido por razones humanitarias como consecuencia de la necesidad de recibir un tratamiento médico a raíz de un grave accidente, tiene derecho a que su hijo, que ha residido siempre en Turquía y ha crecido en el entorno cultural y lingüístico de este pais, obtenga un permiso para residir con sus padres.

que les configura el Convenio Europeo de Derechos Humanos, establezcan limitaciones a los derechos garantizados por el propio Convenio. El escrutinio se establece en tres puntos:

1. Las limitaciones han de estar descritas en ley (norma jurídica preexistente a la limitación, de rango concorde con el sistema de fuentes del Estado en cuestión, elaborada con la precisión suficiente para que los ciudadanos puedan acomodar a ella su conducta, que ha de poder ser conocida por sus destinatarios y ha de contener garantías suficientes contra los abusos).

2. Las limitaciones han de ser necesarias en una sociedad democrática para alcanzar finalidades legítimas y justificadas en forma objetiva y razonable.

3. Las limitaciones han de ser proporcionadas a la causa que las originó y a la finalidad legitima con ellas pretendida. 
El Tribunal Europeo considera que es necesario alcanzar un justo equilibrio entre los intereses del individuo y los de la sociedad en su conjunto. En este sentido, los Estados tienen derecho a controlar la entrada de extranjeros en su territorio y ello gozando de un cierto margen de apreciación, al mismo tiempo que los individuos tienen derecho al respeto a su vida familiar.

Habida cuenta que, si bien los esposos Gül residen en Suiza de manera legal, no disponen de un derecho de residencia permanente $y$ que no existe un obstáculo decisivo para el desarrollo de una vida familiar en Turquía, a lo que se añade el hecho de que su hijo haya vivido siempre en ese país, el Tribunal Europeo considera que la negativa a acoger en Suiza al hijo de los demandantes no constituye una violación del Convenio.

b) Respecto a la unidad familiar el TEDH afirma que la denegación de la prórroga del permiso de residencia a un extranjero divorciado y padre de familia origina una ruptura de la unidad familiar con relación a los hijos que no es compatible con el Convenio Europeo (Caso Berrehab).

En este supuesto el TEDH examina la denegación de una prórroga de residencia a un extranjero divorciado que, con anterioridad a la denegación de la prórroga de la autorización de residencia en los Países Bajos, visitaba regular y frecuentemente a su hija. EI TEDH considera que, en este caso, el vínculo de vida familiar, aunque no aplicable con relación al cónyuge neerlandés puesto que existía divorcio, se mantenía entre el padre y la hija.

De acuerdo con la legislación de los Países Bajos, la denegación de la prórroga del permiso de residencia, originaba la expulsión del recurrente del territorio neerlandés, impidiéndose así que continuara la relación familiar preexistente entre el demandante y su hija.

Para el TEDH es decisivo el hecho de que no se trata de una solicitud de un primer permiso de residencia, sino de una prórroga en favor de una persona que había residido legalmente durante varios años en los Países Bajos y que había tenido un hijo de su matrimonio con una neerlandesa. Tras reconocer que los Estados tienen un amplio margen de discrecionalidad para regular las entradas y la residencia de los extranjeros, el TEDH consideró desproporcionada la ruptura de la unidad familiar existente entre el padre y la hija, que se originaba con la denegación de la prórroga del permiso de residencia. 
c) Respecto de la protección de la vida familiar como límite a las expulsiones de personas extranjeras:

En este punto el Tribunal Europeo de Derechos Humanos ha analizado la protección de la vida familiar desde distintas perspectivas, habida cuenta las diferentes circunstancias que originan los mandatos de expulsión ordenados por los Estados. Así, la existencia de arraigo familiar (Asunto Moustaquim contra Bélgica), la puesta en peligro de la persistencia misma de un matrimonio (Asunto Beljoudi contra Francia), o la necesidad de protección del vínculo familiar de un extranjero condenado penalmente aquejado de sordomudez congénita (Asunto Nasri contra Francia), son considerados por el TEDH como límites al derecho de los Estados a expulsar de su territorio a personas extranjeras. Varios casos contra Francia (Asuntos Mehemi, El Boujaidi, Boujlifa y Dalia) abordan el problema de la obtención del equilibrio necesario para que el respeto al derecho a la vida familiar sea compatible con las necesidades de protección de la seguridad de las personas o de la salud pública. $Y$, desde otro orden de consideraciones, el TEDH considera compatibles con el Convenio las expulsiones de extranjeros condenados penalmente que mantenian vínculos con su pais de origen (Asunto C. contra Bélgica y Asunto Bouchelkia contra Francia). En este sentido hay que resaltar los siguientes criterios jurisprudenciales:

- Las expulsiones de extranjeros son desproporcionadas cuando se ha vivido largo tiempo en el pais y la familia demuestra su arraigo (Caso Moustaquim).

El demandante vivía en Bélgica desde hace más de veinte años (llegó a Bélgica con dos), donde también residian sus padres y sus siete hermanos; además, había seguido toda su escolaridad en francés. Mantenía relación regular y estable con su familia y, pese a la opinión contraria de la Comisión Consultiva de Extranjeros, recibió una orden de expulsión del territorio por parte de las autoridades belgas, con la argumentación de habia cometido reiterados actos delictivos por los cuales había sido condenado y privado de libertad en varias ocasiones.

El Tribunal Europeo constata que la orden de expulsión se había dictado de conformidad con las normas reguladoras del acceso, la permanencia en el territorio y la expulsión de extranjeros y reconoce la ne- 
cesidad de que los Estados puedan controlar estas cuestiones. Lo que sí discute el TEDH es que la aplicación de esta normativa al demandante resulte proporcionada a la finalidad legítima perseguida.

A estos efectos, para el TEDH la vida familiar del demandante se ha visto efectiva y gravemente perturbada por la medida adoptada contra él y que en este supuesto, tratándose de una persona que ha vivido más de veinte años junto a los suyos sin separarse de ellos, no ha existido un justo equilibrio entre los distintos intereses en juego. EI TEDH apreció violación del Convenio.

- La expulsión de un extranjero casado con un nacional de un Estado signatario del Convenio pone en peligro la unidad familiar y la subsistencia del matrimonio (Caso Beldjoudi).

En este supuesto se trata de un nacional argelino (nacido en Francia de padres entonces franceses, que había poseido la nacionalidad francesa durante varios años y que habia sido declarado apto para realizar el servicio militar por las autoridades francesas), residente en Francia y casado con una francesa hija de franceses desde hace varias décadas. Había sido condenado por la realización de varios delitos $y$, alegando razones de orden público, las autoridades francesas dictaron orden de expulsión del territorio. Para el TEDH el único vínculo del demandante con Argelia era el de la nacionalidad puesto que, incluso, éste había seguido su escolaridad en francés y no parecía conocer la lengua árabe.

EI TEDH considera que, de hacerse efectiva la expulsión, si los esposos querian mantener la unidad familiar, la esposa debería residir en el extranjero, en un Estado cuya lengua probablemente ignorara y con un tal desarraigo que podía originarle graves problemas de adaptación e incluso de carácter jurídico. En consecuencia, el TEDH, que como en otros supuestos no discute la capacidad y legitimidad de los Estados para tomar medidas de salvaguarda del orden público y de control sobre la permanencia y la expulsión de extranjeros, considera que la expulsión del demandante pone, en este caso concreto, en peligro la unidad o incluso la propia subsistencia del matrimonio. Estos efectos, para el TEDH, no resultarían proporcionados a la finalidad legítima perseguida y originarian una violación del respeto a la vida familiar exigido por el Convenio. 
- La expulsión de una persona aquejada de enfermedad que precise un tratamiento en un entorno familiar es contraria al Convenio aunque se trate de un extranjero condenado penalmente (Asunto Nasri contra Francia).

En este supuesto se trataba del súbdito argelino residente en Francia, aquejado de sordomudez congénita y condenado por el delito de violación en grupo. El Tribunal Europeo considera que para un individuo confrontado a tales obstáculos, la familia presenta una importancia muy particular, no únicamente como medio de acogida, sino, sobre todo, para seguir el tratamiento adecuado para su sordomudez y para ayudarle a no volver a caer en la delincuencia.

A mayor abundamiento, el Sr. Nasri, pese a frecuentar la comunidad magrebí, no comprendía la lengua árabe y siguió en Francia los pocos cursos escolares a los que asistió. Siempre había compartido el domicilio de sus padres o de una hermana y nunca rompió con su familia. Seis de sus nueve hermanos habían adquirido la nacionalidad francesa.

Habida cuenta de todas estas circunstancias, el Tribunal Europeo considera que el Sr. Nasri precisa de un tratamiento especializado y no puede encontrar un mínimo de equilibrio psicológico y social más que en su familia, compuesta mayoritariamente de ciudadanos franceses que no tienen ningún vínculo con Argelia. Como consecuencia, la decisión de expulsar al recurrente no sería proporcionada a la luz del art. 8 del Convenio.

- La expulsión de un extranjero condenado penalmente, que tiene vínculos familiares con su país de origen, no es contraria al Convenio (Asunto C. contra Bélgica y Asunto Bouchelkia contra Francia).

En el primer caso, el Sr. C. había establecido en Bélgica vínculos sociales reales, puesto que allí habia recibido una formación escolar y trabajado durante varios años. Residía en Bélgica desde los 11 años, donde había vivido con sus padres $y$ sus hermanos $y$, ulteriormente, con su mujer y su hijo, nacido y escolarizado también en Béłgica. Sin embargo, su vida familiar se hallaba también vinculada, al menos en parte, a su país de origen, en donde habia contraido matrimonio con una marroquí y había tenido un hijo con ella, habiéndose 
divorciado posteriormente y concluido un acuerdo atribuyendo al padre la custodia del hijo; el mismo padre del Sr. C. había vivido y fallecido en Marruecos. Su condena por posesión ilicita de estupefacientes y asociación de malhechores, debido a su concurso a la comercialización de cannabis, originó una orden de expulsión por parte del Gobierno belga.

El Tribunal Europeo de Derechos Humanos tiene que analizar en este caso si la injerencia en la vida familiar originada por la orden de expulsión era compatible con el Convenio. A este respecto, habida cuenta de la naturaleza de los vínculos del recurrente con Bélgica y con Marruecos, así como de la gravedad de las infracciones que han originado su expulsión, el TEDH considera que no se ha demostrado que las autoridades belgas hayan actuado en forma arbitraria o irrazonable, 0 incumplido su obligación de garantizar un justo equilibrio entre los intereses en juego. De tal modo que la expulsión sería, en este caso, compatible con el Convenio.

En el segundo de los casos, el Tribunal Europeo tuvo que dilucidar si el Sr. Bouchelkia, sometido a una orden de expulsión por condena a causa de delito de violación con agravantes, tiene derecho a permanecer en territorio francés debido a sus vínculos familiares.

EI TEDH consideró que hay que analizar cual era la situación personal del demandante en el momento en que se acordó la orden de expulsión. En esa fecha el Sr. Bouchelkia tenía 17 años, era soltero y sin hijos y no fundó su propia familia más que posteriormente al decreto de expulsión. Paralelamente, el Sr. Bouchelkia mantenía vínculos con su pais de origen y en él residian parientes cercanos.

EI TEDH valoró la naturaleza del delito que motivó la orden de expulsión, que el Sr. Bouchelkia no tenía vínculos familiares que le arraigaran en Francia $y$ que las autoridades francesas podian considerar legítimamente que la expulsión era necesaria para la defensa del orden y la prevención de infracciones penales, por lo que consideró como compatible con el Convenio la expulsión del Sr. Bouchelkia del territorio francés ${ }^{32}$.

32 Esta sentencia del TEDH presenta, a nuestro parecer, ciertos problemas en relación con la apreciación de las circunstancias que parecen lograr el equilibrio entre los intereses en juego. Por una parte, el TEDH aprecia, con criterios estrictamente formales, la situación de la persona objeto de la orden de expulsión únicamente en el momento de dictarse tal orden, sin tener en cuenta ni su edad (17 años) ni el establecimiento posterior de vínculos familiares en territorio francés (la for- 
- Los Estados deben encontrar un equilibrio entre, por una parte, el respeto a la vida familiar $y$, por otra, la protección del orden público y la prevención de infracciones penales (Asuntos Mehemi, El Boujaidi, Boujlifa y Dalia, todos contra Francia).

En estos cuatro casos, el Tribunal Europeo aborda el problema de las expulsiones de extranjeros condenados penalmente y sujetos a una orden de expulsión que, por otra parte, tienen establecidos vínculos familiares en el país de acogida. Como sea que en el art. $8 \mathrm{CEDH}$ se exige el respeto a la vida familiar al mismo tiempo que se permiten, con una serie de requisitos, ciertas injerencias de los Estados al respecto, el TEDH considera que hay que encontrar un cierto equilibrio entre el derecho proclamado (el respeto a la vida familiar) y las injerencias previstas (la necesidad de preservar el orden público y la prevención de infracciones penales).

Con este objetivo, el TEDH configura una serie de criterios, a veces sin excesiva coherencia en su aplicación al caso concreto, que determinan la legitimidad o no de las órdenes de expulsión.

Asi, en el Asunto Mehemi, el hecho de haber nacido en Francia, residir en este país durante más de treinta años, siendo los padres del demandante y sus cuatro hermanos residentes legales en Francia y tener su esposa y sus tres hijos menores la nacionalidad francesa, permiten al TEDH considerar contraria al Convenio la decisión de expulsión, pese a que el demandante había sido condenado penalmente por tenencia y venta de drogas.

Por el contrario, cuando existen varias condenas penales, el TEDH decanta la solución del caso a favor de la compatibilidad de la orden de expulsión con las garantías del Convenio. Ello sucede así en el Asunto El Boujaidi y en el Asunto Boujlifa, donde, pese a la existencia de hijos de nacionalidad francesa y de padres y hermanos residentes en Francia, la gravedad de las infracciones y de las condenas resultan-

mación de una familia propia con posterioridad a la orden de expulsión). No ha tenido en cuenta tampoco que residía desde los dos años en territorio francés y que hasta que formó su propia familia había vivido en Francia con sus padres. La apreciación de la fecha de la orden de expulsión como momento procesal único en el que podia enjuiciarse a la luz del Convenio la orden de expulsión aparece como un criterio insuficiente, puesto que procesalmente también podia haberse seguido el criterio de tener en cuenta la fecha en la que orden de expulsión debía ser hecha efectiva $y$, en tal supuesto, el Sr. Bouchelkia tenía lazos familiares de naturaleza mucho más fuerte en territorio francés. 
tes justifican, a juicio del TEDH, las expulsiones decretadas por las autoridades francesas.

En el Asunto Dalia, la demandante, también objeto de condena penal, pese a haber vivido 19 años en Argelia y otros 19 en Francia, únicamente podía probar un vínculo familiar efectivo con relación a la existencia de un hijo de doble nacionalidad franco-argelina. En este caso, el Tribunal Europeo consideró que la injerencia del Estado no era tan fuerte como en otros supuestos en los que la expulsión podía recaer sobre personas que habían llegado al país de acogida con muy corta edad y que, desde otro orden de consideraciones, nada impedia que pudiera desarrollar su vida familiar con su hijo en Argelia, donde mantenía también vínculos familiares y sociales. De este modo, el TEDH llegó a la conclusión de que la expulsión de la demandante no constituía violación alguna del art. 8 del Convenio.

\section{Con relación a las retenciones de extranjeros en las zonas internacionales de los aeropuertos}

Al Tribunal Europeo de Derechos Humanos se le ha planteado también si la retención de extranjeros inmigrantes en situación irregular en las denominadas zonas internacionales de los aeropuertos es o no compatible con el Convenio Europeo de Derechos Humanos (Asunto Amuur contra Francia).

El conflicto se planteó en este caso cuando en el aeropuerto de París-Orly se retuvo durante 20 días en la zona de tránsito de este aeropuerto a varias personas que declararon huir de su país de origen (Somalia) por ser perseguidos políticos y encontrarse su vida en peligro. Procedian de Damasco, pero el título de viaje era falso y por ello se les prohibió la entrada en territorio francés. Cuando se les denegó el asilo político fueron reenviados a Siria sin que se hubieran podido dirigir de modo útil a la autoridad competente para pronunciarse sobre su condición de refugiados.

En la sentencia que comentamos, el Tribunal Europeo sienta diversos criterios con relación a este tipo de retenciones:

a) Las zonas de tránsito o internacionales de los aeropuertos, con independencia de su denominación, no se benefician del estatuto de extraterritorialidad. Como consecuencia, en estas zonas debe poder aplicarse con eficacia la legislación vigente en el Estado donde esté situado el aeropuerto. 
b) Las retenciones de inmigrantes ilegales en las zonas internacionales de los aeropuertos, para que puedan ser compatibles con las exigencias del Convenio Europeo, deben ser efectuadas con una serie de garantías:

- La retención no puede ser prolongada en forma excesiva, puesto que en tal caso no se trataría de una retención sino de una verdadera privación de libertad.

- La prolongación de una retención necesita el control no demasiado tardío del juez, controlador natural de las situaciones de privación de libertad.

- Durante una retención, con independencia de la decisión final que se tome al respecto, no se puede impedir el acceso eficaz al procedimiento de determinación del estatuto de refugiado.

- Para que este acceso al procedimiento de obtención del estatuto de refugiado sea efectivo es necesaria la concesión de asistencia jurídica y social.

- Durante todo el tiempo en que dure la retención, es necesario observar las normas, tanto de fondo como de procedimiento vigentes en el país las cuales, además, han de ser compatibles con las exigencias del Convenio Europeo.

Dado que en este caso, las personas retenidas en el aeropuerto de París-Orly, lo fueron durante veinte dias, colocadas bajo una vigilancia policial estricta y constante, sin que se beneficiaran de ningún tipo de asistencia jurídica ni social, sin que todo ello fuera objeto de control judicial y sin que se observaran las normas francesas aplicables a las privaciones de libertad, el Tribunal Europeo de Derechos Humanos consideró que se había violado el Convenio.

\section{A MODO DE CONCLUSIÓN}

Del examen del Convenio Europeo de Derechos Humanos y de la jurisprudencia del Tribunal de Estrasburgo aplicable a los derechos de los extranjeros podemos deducir una serie de construcciones interpretativas que, a la luz del art. $10.2 \mathrm{CE}$, han de ser tenidas en cuenta en todo análisis que se realice de los derechos de los extranjeros en el sistema jurídico español. En tal sentido, si bien los Estados gozan de cierta discrecionalidad para regular las políticas migratorias y los derechos 
de los extranjeros, esta discrecionalidad no es absoluta y debe ejercitarse dentro del marco de garantía establecido por el Convenio Europeo de Derechos Humanos y de las construcciones jurisprudenciales que, como órgano de interpretación y aplicación del Convenio, han sido configuradas por el Tribunal de Estrasburgo.

\section{NOTA BIBLIOGRÁFICA}

Pese a que este trabajo tiene como objeto principal el análisis y enjuiciamiento de las sentencias del Tribunal Europeo de Derechos Humanos $y$, como consecuencia, sus fuentes son básicamente jurisprudenciales, queremos destacar, de entre la ya abundante doctrina existente en materia de extranjería ${ }^{33}$, aquellas obras, tanto de alcance general como incidentes en aspectos concretos de la misma, que pueden proporcionar elementos de análisis relevantes para un mejor y más completo estudio de este problema.

\section{Estudios monográficos generales sobre extranjeros}

Además de los correspondientes capítulos de prácticamente todos los manuales de Derecho Constitucional y de Derecho Internacional y de los libros relativos a Derechos Humanos o Derechos Fundamentales, destacaremos los estudios monográficos siguientes:

BorRajo INIESTA, I.: "El "status" constitucional de los extranjeros». En Estudios sobre la Constitución. Homenaje al profesor Eduardo García de Enterría. Vol II, Cívitas, Madrid, 1991.

33 Pese a que sustantivamente no contemplan la jurisprudencia del TEDH aplicable a derechos de los extranjeros y se refieren a construcciones generales interpretativas del Tribunal Europeo, hemos de señalar que hemos seguido en diversos puntos de este trabajo otras publicaciones nuestras anteriores: Así, en relación con los criterios interpretativos generales elaborados por el TEDH acerca de los escrutinios utilizados para determinar las exigencias con que deben cumplir los límites a los derechos y para delimitar las exigencias de la igualdad, el trato diferente y la no discriminación, el artículo de FREIXES, T., "Las principales construcciones jurisprudenciales del Tribunal Europeo de Derechos Humanos". Cuadernos Constitucionales de la Cátedra Fadrique Furió Ceriol, n. 11/12, 1995. 
Escuin Palop, V.: Régimen jurídico de la entrada y permanencia de extranjeros en España. Centro de Estudios Constitucionales, Madrid, 1991.

Ferrer Peña, R. M.: Los derechos de los extranjeros en España. Tecnos, Madrid, 1989.

FLoRES GIMENEZ , F.: "La normativa para los extranjeros no comunitarios en España». Revista General de Derecho, n. 585, 1993.

Freixes Sanjuan, T.: “Constitución, derechos de los extranjeros y políticas de extranjería". En A. Marrazo (Coord): Derechos humanos del incapaz, del extranjero, del delincuente y complejidad del sujeto. Bosch, Barcelona, 1997.

Freixes Sanjuán, T. y Remomi Carbonell, J. C.: "Los derechos de los extranjeros en el ámbito del Consejo de Europa: especial referencia a la jurisprudencia del Tribunal Europeo de Derechos Humanos». Migraciones, $\mathrm{n}^{\circ}$ 2, Universidad Pontificia de Comillas, Madrid, 1997.

Miguel Calatayud, J. A.: Estudios sobre Extranjería. Bosch, Barcelona, 1987.

SagarRa Trias, E.: Los derechos fundamentales y las libertades públicas de los extranjeros en España. Bosch, Barcelona, 1991.

Santamaría lbeas, J. J.: "Los derechos fundamentales y el Tribunal Constitucional. Los infraderechos de los extranjeros en España. Reflexiones sobre la jurisprudencia constitucional". Derechos y Libertades. Revista del Instituto Bartolomé de las Casas, n. ${ }^{\circ}$ 2, 1994.

Estudios sobre cuestiones concretas relacionadas con los extranjeros

Entre los estudios acerca de aspectos puntuales o derechos concretos relacionados con los extranjeros quiero mencionar los que siguen:

Arnaldo Alcubilla, E.: "El derecho de sufragio de los extranjeros en las elecciones locales". Revista Española de Derecho Constitucional, n. ${ }^{\circ} 34,1992$.

BelloCh, J. A.: "Los derechos del "extranjero": El internamiento preventivo y su homologación judicial". En Privaciones de libertad y Derechos Humanos, Hacer, Barcelona, 1987. 
Cruz Villalón, P.: "Dos cuestiones de titularidad de derechos: los extranjeros; las personas jurídicas". Revista Española de Derecho Constitucional, n. ${ }^{\circ} 25,1989$.

FERnÁndez ZubizARRETA, S.: "Derecho al trabajo del extranjero en el ordenamiento jurídico español». En Privaciones de libertad y Derechos Humanos, Hacer, Barcelona, 1987.

Freixes Montes, J.: “Els drets dels estrangers: especial referència a l'entrada i permanència en territori espanyol». Revista Jurídica de Catalunya, n. ${ }^{\circ}$, 1994.

López GarRido, D.: El derecho de asilo. Trotta, Madrid, 1991.

Rallo Lombarte, A.: "El Tratado de Maastricht y el derecho de sufragio de los extranjeros en España». Revista de Derecho Político, n. ${ }^{\circ}$ 36, 1993.

Sagarra Trías, E.: "El Dret d'Asil i la Condició de refugiat». Revista Juridica de Catalunya, $n .^{\circ} 4,1987$ (actualizado en «El derecho de asilo y la condición de refugiado en España». Cuadernos de Derecho Judicial, Consejo General del Poder Judicial, 1995).

“El vot dels estrangers en les eleccions municipals». Revista Jurídica de Catalunya, $\mathrm{n}^{\circ}$ 3, 1991.

\section{JURISPRUDENCIA DEL TRIBUNAL EUROPEO DE DERECHOS HUMANOS SOBRE DERECHOS DE LOS EXTRANJEROS}

- Asunto Pakelli contra República Federal Alemana. STEDH de 25 de abril de 1983. Série A des publications de la Cour, n. ${ }^{\circ} 64$.

- Asunto Sramek contra República Federal Alemana. STEDH de 22 de octubre de 1984. Série A des publications de la Cour, n. ${ }^{\circ} 84$.

- Asunto MacGoff contra Suecia. STEDH de 26 de octubre de 1984. Série A des publications de la Cour, $n .^{\circ} 83$.

- Asunto Abdulaziz, Cabales y Balkandali contra el Reino Unido. STEDH de 25 de mayo de 1985. Série A des publications de la Cour, n. ${ }^{\circ} 94$.

- Asunto O. contra el Reino Unido. STEDH de 9 de junio de 1988. Série A des publications de la Cour, n. ${ }^{\circ} 136-\mathrm{A}$.

- Asunto Berrehab contra los Países Bajos. STEDH de 21 de junio de 1988. Série A des publications de la Cour, $\mathrm{n} .^{\circ} 138$. 
- Asunto Soering contra el Reino Unido. STEDH de 7 de julio de 1989. Série A des publications de la Cour, n. ${ }^{\circ} 161$.

- Asunto Moustaquim contra Bélgica. STEDH de 18 de febrero de 1991. Série A des publications de la Cour, n. 193.

- Asunto Cruz Varas contra Suecia. STEDH de 20 de marzo de 1991. Série A des publications de la Cour, n. 201.

- Asunto Beldjoudi contra Francia. STEDH de 26 de marzo de 1992. Série A des publications de la Cour, n. ${ }^{\circ}$ 234-A.

- Asunto Nasri contra Francia. STEDH de 13 de julio de 1995. Série A des publications de la Cour, $\mathrm{n} .^{\circ} 320-\mathrm{B}$.

- Asunto Gül contra Suiza. STEDH de 19 de febrero de 1996 (todavía no publicada en la Série $A$ des publications de la Cour). Ref. ${ }^{a}$ Internet 1996-634.

- Asunto Amuur contra Francia. STEDH de 25 de junio de 1996. Ref. ${ }^{a}$ Internet 1996-634.

- Asunto C. contra Bélgica. STEDH de 7 de agosto de 1996. Ref. ${ }^{a}$ Internet 1996-647.

- Asunto Gaugusuz contra Austria. STEDH de 16 de setiembre de 1996. Ref. ${ }^{a}$ Internet 1996-655.

- Asunto Chahal contra el Reino Unido. STEDH de 15 de noviembre de 1996. Ref. ${ }^{a}$ Internet 1996-697.

- Asunto Ahmed contra Austria. STEDH de 17 de diciembre de 1996. Ref. ${ }^{a}$ Internet 1996-706.

- Asunto H.L.R. contra Francia. STEDH de 29 de abril de 1997. Ref. ${ }^{a}$ Internet 1997-757.

- Asunto D. Contra el Reino Unido. STEDH de 2 de mayo de 1997. Ref. ${ }^{a}$ Internet 1997-758.

- Asunto Mehemi contra Francia. STEDH de 26 de septiembre de 1997. Ref. ${ }^{a}$ Internet 1997-826.

- Asunto El Boujaidi contra Francia. STEDH de 26 de septiembre de 1997. Ref. ${ }^{a}$ Internet 1997-827.

- Asunto Boujlifa contra Francia. STEDH de 21 de octubre de 1997. Ref." Internet 1997-842.

- Asunto Dalia contra Francia. STEDH de 19 de febrero de 1998. Ref. ${ }^{a}$ Internet 1998-870. 
- Asunto Bahaddar contra los Países Bajos. STEDH de 19 de febrero de 1998. Ref. ${ }^{a}$ Internet 1998-876.

- Asunto Ali contra Suiza. STEDH de 5 de agosto de 1998. Ref. ${ }^{a}$ Internet 1998-950.

- Asunto Soumare contra Francia. STEDH de 24 de agosto de 1998. Ref. ${ }^{a}$ Internet 1998-958.

- Asunto Erkalo contra los Países Bajos. STEDH de 2 de septiembre de 1998. Ref. ${ }^{a}$ Internet 1998-968.

- Asunto B.B. contra Francia. STEDH de 7 de septiembre de 1998. Ref. ${ }^{a}$ Internet 1998-985. 